\title{
Effect of cattle and wildlife exclusion areas on the survival and growth of Pinus culminicola Andresen \& Beaman
}

\section{Efecto de las áreas de exclusión para ganado y fauna silvestre en la sobrevivencia y crecimiento de Pinus culminicola Andresen \& Beaman}

\author{
Javier Jiménez-Pérez ${ }^{1}$, José Israel Yerena-Yamallel ${ }^{1 *}$, Eduardo Alanís-Rodríguez ${ }^{1}$, Oscar Aguirre-Calderón $^{1}$, \\ René Martínez-Barrón ${ }^{1}$ \\ ${ }^{1}$ Universidad Autónoma de Nuevo León, Facultad de Ciencias Forestales, Carretera Nacional km 145, CP. 67700, Linares, \\ Nuevo León, México. \\ ${ }^{*}$ Corresponding author: israel.yerena@gmail.com
}

Scientific note received: March 15, 2016 accepted: August 29, 2017

\begin{abstract}
In 1997, a restoration of Pinus culminicola was established under three exclusion areas: $\mathrm{E} 1=$ cattle plus small mammal exclusion, E2 = cattle exclusion and E3 = no exclusion (free range), in the Cerro El Potosi Protected Natural Area, located in Nuevo León, Mexico. The objective of this study was to determine the survival rate and the increase in diameter and height of Pinus culminicola individuals at three and 17 years after planting. The results show differences between 2000 and 2014 in survival rate and diameter and height growth in the three exclusion areas; E1 and E2 recorded higher averages. The main causes of mortality in this species are attributed to extreme weather conditions and the damage caused by cattle and small mammals.
\end{abstract}

Key words: Degradation, exclusion, Pinus culminicola, restoration, survival

RESUMEN. En 1997 se estableció una restauración de Pinus culminicola en tres áreas de exclusión: E1 = exclusión de ganado mayor + exclusión de mamíferos menores, E2 = exclusión de ganado mayor y E3 = sin exclusión, en el Área Natural Protegida Cerro El Potosí, Nuevo León, México. El objetivo fue determinar el porcentaje de sobrevivencia y el incremento en diámetro y altura de individuos de Pinus culminicola a tres y 17 años de plantación. Los resultados muestran diferencias entre el 2000 y 2014 en el porcentaje de sobrevivencia y crecimiento en diámetro y altura en las tres áreas de exclusión, en E1 y E2 se tuvieron los mayores promedios. Las causas principales de mortalidad de $P$. culminicola se atribuyen a las condiciones climáticas extremas, al daño ocasionado por el ganado y los mamíferos menores.

Palabras clave: Degradación, exclusión, Pinus culminicola, restauración, sobrevivencia

\section{INTRODUCTION}

Ecological restoration is defined as the process of assisting the recovery and reestablishment of an ecosystem that has been degraded, damaged or destroyed (SER 2004) by anthropogenic activities that affected its diversity and dynamics (Jackson et al. 1995). It is defined as a long-term vision, based on a set of actions in which natural succession is assisted and facilitated (Ruiz and Mitchell 2005) for the regeneration and recovery of a habitat $(\mathrm{Ce}-$ lentano et al. 2011), as well as the structure and function of the ecosystem (Barrera and Ríos 2002). Restoration represents a way to improve human wellbeing in the long term, through the recovery of soil productivity and natural capital, as well as the provision of goods and services (Chazdon 2008).

Pinus culminicola Andresen et Beaman is an endemic species that is located in the Sierra Madre Oriental, with an altitudinal distribution between 3 300 and 3450 masl. It is listed as a species in danger of extinction by NOM-059-SEMARNAT-2010 
(SEMARNAT 2010) and endangered (EN) by the Red List of Internationally Threatened Species. This species is distributed in a limited area of the Cerro El Potosí Protected Natural Area (PNA) in Galeana, Nuevo León and Sierra La Viga in Ramos Arizpe, in the state of Coahuila, Mexico (Favela 2010).

In 1978, a series of wildfires devastated a wooded area of the Cerro El Potosí PNA, resulting in a $34 \%$ decrease in the area occupied by this vegetation (García et al. 1999). In 1998, several wildfires decreased the Pinus culminicola distribution area, causing the area evaluated by Beaman and Andresen in 1966 (106 ha) to decrease to its present size of no more than 30 ha, where the population of $\mathrm{Pi}$ nus culminicola occurs in small groups with overmatured individuals and therefore a low production of germplasmic material (Jiménez et al. 1999).

After wildfires in priority management areas, such as Natural Protected Areas, it is common for ecological restoration measures to be implemented immediately (Beghin et al. 2010). The most common practices worldwide are the planting of woody plants (Jiménez et al. 2005) and the placement of soil retention works (Myronidis et al. 2010). A loss of the natural regeneration of the diverse species of conifers located within the PNAs is due to the wild fauna and the grazing of domestic livestock, specifically in the Cerro El Potosí PNA where the presence of cattle does not allow the development of natural regeneration of $P$. culminicola, being a limiting factor for the development and distribution of this species (Jiménez et al. 2005). Therefore, the objective of this study was to determine the survival rate and the increase in diameter and height of $P$. culminicola individuals at three and 17 years after planting in the Cerro El Potosí Protected Natural Area.

\section{MATERIALS AND METHODS}

\section{Study area}

The study area is located at 3300 masl in the Cerro El Potosí Protected Natural Area, located in the southeastern region of the state of Nuevo León, Mexico (Figure 1). This mountainous massif corresponds to the Sierra Madre Oriental, which is located between the Gulf Coastal Plain and the Mexican Altiplano. Due to its high percentage of endemic species, and its geographic and topographical distribution with respect to other mountains, it has been the center of study of several authors (Beaman and Andresen 1966, Jiménez et al. 1996).

\section{Evaluation of exclusion areas}

In December 1997, a restoration of P. culminicola was carried out in excluded and non-excluded areas, establishing three different exclusion area systems: $\mathrm{E} 1=$ cattle plus small mammal exclusion, E2 = cattle exclusion and E3 = no exclusion (free range). Each exclusion area contained 110 individuals at an approximate density of two plants per $10 \mathrm{~m} 2$ (2,000 plants ha). It is important to note that due to the cost of establishing this type of restoration, no repetitions of the same exclusion areas were made.

The survival of Pinus culminicola was determined to estimate the proportion of live individuals with respect to planted trees, by means of formula 1 (CNF 2013).

$$
P=\left(\frac{\sum_{i=1}^{n} a_{i}}{\sum_{i=1}^{n} m_{i}}\right) * 100
$$

Where $P$ is the proportion of live individuals, $a_{i}$ the number of live trees at site $i$ and $m_{i}$ the number of trees planted at site $i$.

The diameter at neck height (DNH) and the total height $(\mathrm{h})$ of the individuals were also measured at two different times: 3 and 17 years (year 2000 and 2014). The measurement of these dendrometric parameters is based on the existence of seedling development as there is a growth in diameter and height (Jiménez et al. 1996).

\section{Statistical analysis}

To determine the existence of significant differences in the variables total height and diameter at the neck among the exclusion areas, the mean values were estimated. Once the data complied with the criteria of normality and homoscedasticity, 


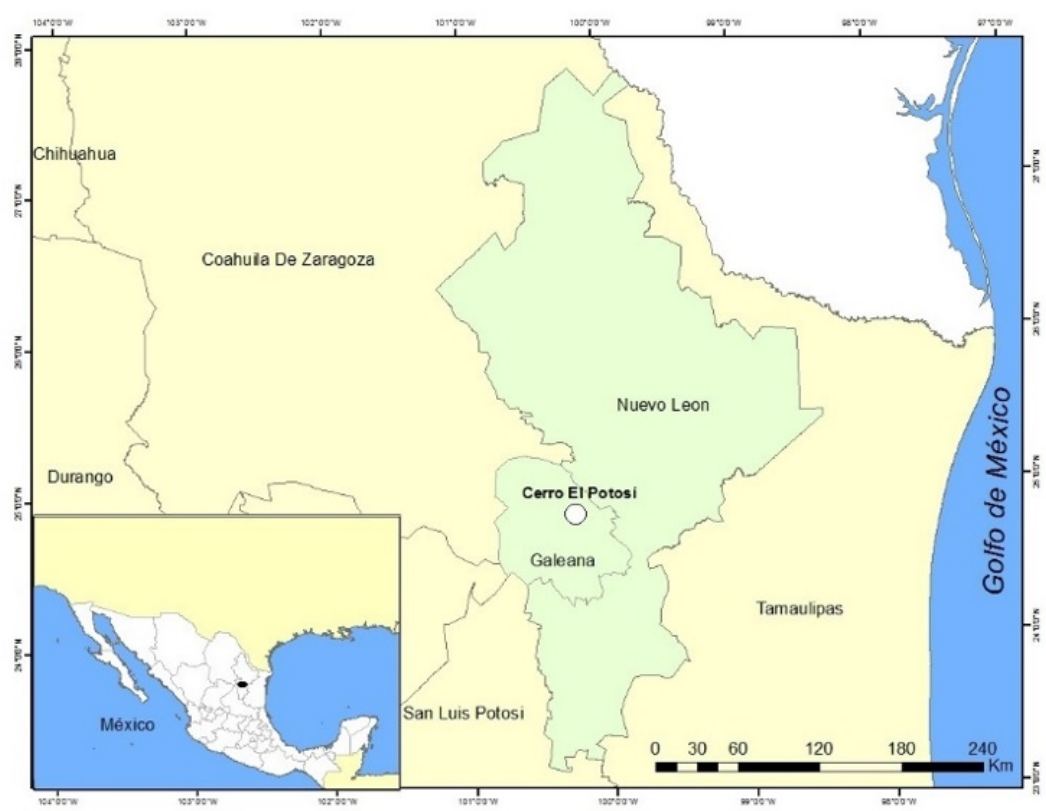

Figure 1. Location of the Cerro El Potosí Protected Natural Area, Nuevo León, Mexico.

a one-way analysis of variance was performed ( $\mathrm{p} \leq$ $0.05)$. In case of obtaining significant differences, a comparison of means analysis was conducted using Tukey's HSD test.

\section{RESULTS AND DISCUSSION}

\section{Survival}

When performing the analysis of the survival variable as a function of the different exclusion areas and based on two different periods ( 3 and 17 years), E1 and E2 showed the highest survival rates for 2000 with 56 and 54, while E3 (without protection) had $28 \%(p=0.008)$. After 17 years, survival in the three exclusion areas decreased $(p=0.056)$ to 27 , 10 and $12 \%$ for E1, E2 and E3, respectively (Figure 2). The decrease in the exclusion areas is due to factors such as extreme climatic conditions typical of the study area, such as low temperatures, strong winds, scarce rainfall, low relative humidity, little soil depth and loss of edaphic material. The survival rates obtained in E3 for 2000 and E1 for 2014 are similar to those obtained by Alanís-Rodríguez et al. (2008) who report $23 \%$ survival in a restored pine- oak forest area, while Lamb and Gilmour (2003) and Celentano et al. (2011) indicate that it is important and necessary to protect the seedlings from any type of external disturbance such as fires and animals, so that the development processes occur naturally, although, according to Meli (2003), they vary depending on the climate, the type of soil, the existing vegetation, and the history and management of the land (Zimmerman et al. 2000, López-Barrera et al. 2007). Therefore, restoration strategies must take into account all possible obstacles (Holl et al. 2000, Gil 2001).

\section{Height}

The average height of the Pinus culminicola seedlings showed differences within the exclusion areas, being higher in E1 in both evaluation years (2000 and 2014). For 2000 the E1 seedlings averaged a height of $13.4 \mathrm{~cm}$, while E2 and E3 had 10.3 and $10.9 \mathrm{~cm}$, respectively $(p=0.011)$ (Figure 3). In 2014 the average height values for E1, E2 and E3 were 57.07, 39 and $34.2 \mathrm{~cm}$, respectively ( $p$ $=0.003$ ) (Figure 3). 


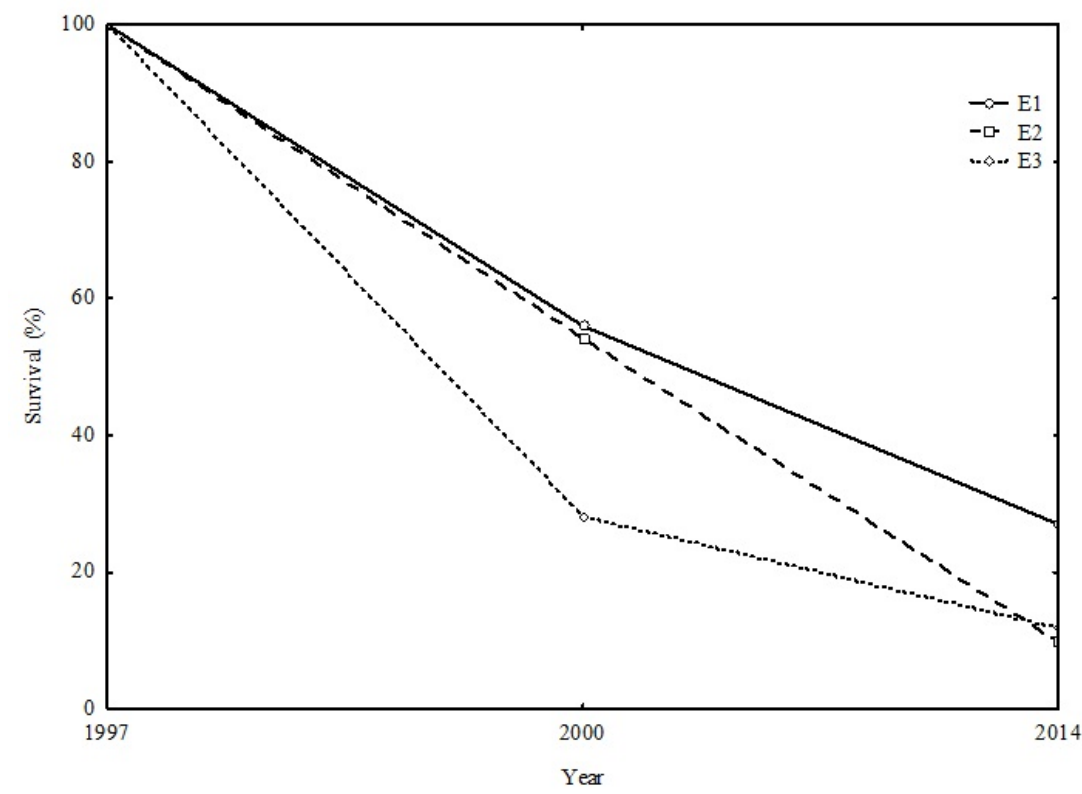

Figure 2. Survival of Pinus culminicola seedlings in relation to exclusion areas. E1 = cattle and small mammal exclusion, E2 = cattle exclusion and E3 = no exclusion.

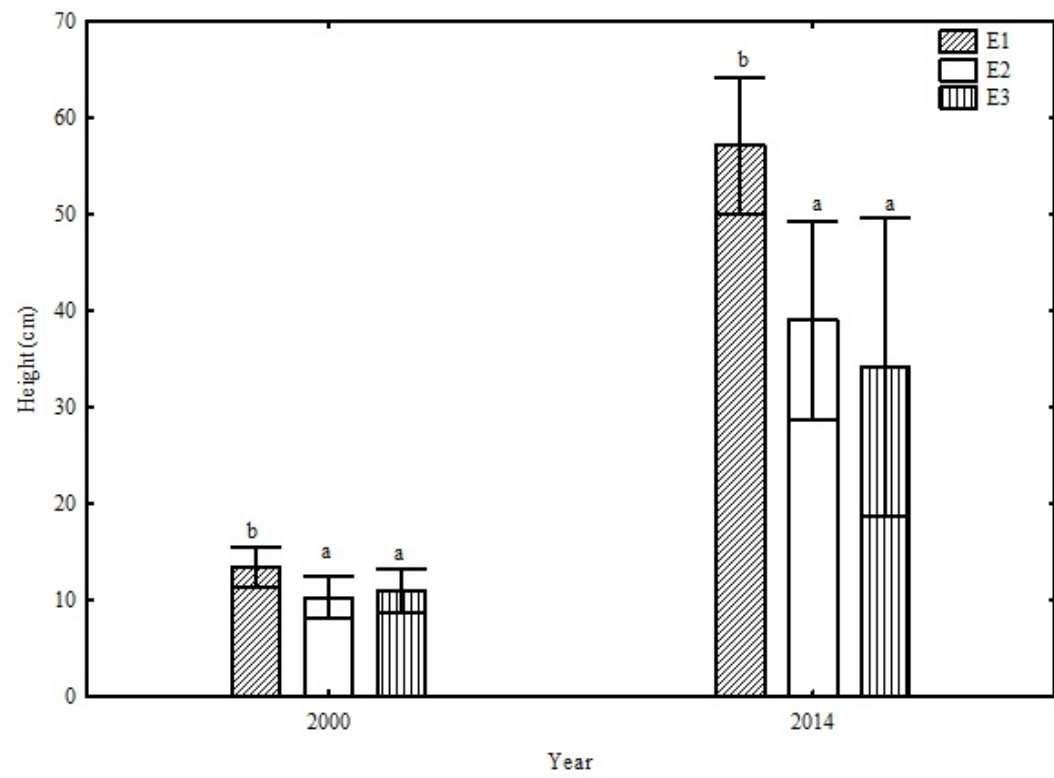

Figure 3. Average height of Pinus culminicola by exclusion area. Significant differences $(p<0.05)$. E1 = cattle plus small mammal exclusion, $E 2=$ cattle exclusion and $\mathrm{E} 3=$ no exclusion.

\section{Diameter at neck height}

There are differences between the neck diameters of the seedlings in the different exclusion areas in $2000(p=0.004)$; the average diameter in
$\mathrm{E} 1$ and $\mathrm{E} 2$ was 2.17 and $1.56 \mathrm{~cm}$, respectively, while E3 had a lower value of $0.9 \mathrm{~cm}$. The neck diameters also showed a difference in $2014(p=0.027)$, having values of $4.36,3.36$ and $1.99 \mathrm{~cm}$ for E1, E2 


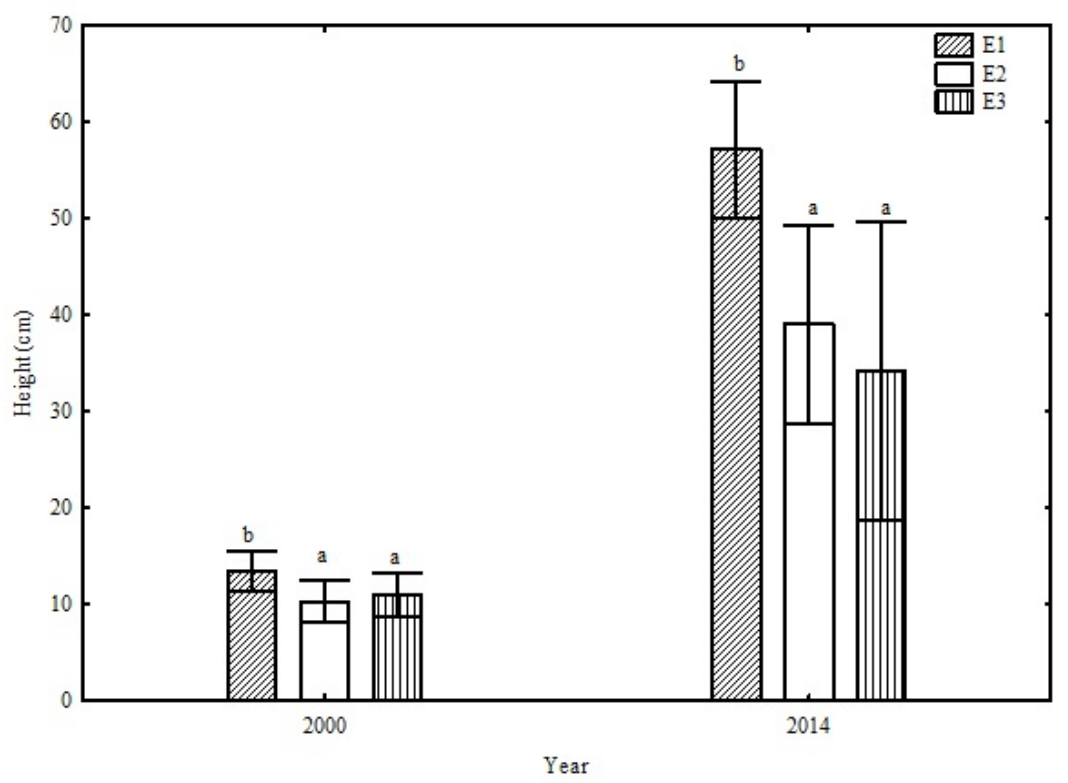

Figure 4. Average diameter of Pinus culminicola by exclusion area. Significant differences $(p<0.05)$. E1 = cattle plus small mammal exclusion, $E 2=$ cattle exclusion and $\mathrm{E} 3=$ no exclusion.

and E3, respectively (Figure 4).

The increase in both plant diameter and height coincides with the findings of Aguirre et al. (2003) who report that in a Pinus culminicola ecosystem the height of the trees varies between 0.9 and $2.9 \mathrm{~m}$ and the diameter between 5.3 and $17.3 \mathrm{~cm}$, but likewise the seedlings were prone to grazing; therefore, and according to Jiménez et al. (1999), livestock is one of the constraints on the development of the plants, although on the other hand Guzmán and Navarro (2005) mention that grazing is a modeling factor in Mediterranean ecosystems, which can cause severe damage to some ecosystems while in others it is a useful management tool (Ferrer and Broca 1999).

The exclusion area against cattle and small mammals proved to be efficient, as it doubles the survival rate, diameter and total height values. This is attributed to the fact that in the areas without exclusion there was the presence of large and small cattle, resulting in trampling of individuals; likewise, rodents caused damage to the apical buds of the plants, which predisposes them to a lower survival rate. It is important to note that Pinus culminicola, due to its shrubby development, does not show the characteristics of other coniferous species, so there is slow development with respect to the dendrometric variables of diameter and height. The results obtained show that the use of seedlings and the application of exclusion areas provide a form of restoration in Pinus culminicola shrubland, due to greater survival of the established individuals and the development of the diameter and height of this species endemic to the Sierra Madre Oriental.

\section{LITERATURE CITED}

Aguirre O, Jiménez J, Kramer H, Akca A (2003) Análisis estructural de ecosistemas forestales en el Cerro del Potosí, Nuevo León, México. Ciencia UANL 6: 219-225.

Alanís-Rodríguez E, Jiménez-Perez J, Espinoza-Vizcarra D, Jurado-Ybarra E, Aguirre-Calderón OA, GonzálezTagle MA (2008) Evaluación del estrato arbóreo en un área restaurada post-incendio en el Parque Ecológico Chipinque, México. Revista Chapingo Serie Ciencias Forestales y del Ambiente 14: 81-87. 
Barrera J, Ríos H (2002) Acercamiento a la ecología de la restauración. Pérez-Arbelaezia 13: 33-46.

Beaman J, Andresen J (1966) The vegetation, floristics and phytogeography of the summit of Cerro Potosí, Mexico. The American Midland Naturalist 75: 1-33.

Beghin R, Lingua E, Garbarino M, Lonati M, Bovio G, Motta R, et al. (2010) Pinus sylvestris forest regeneration under different post-fire restoration practices in the northwestern Italian Alps. Ecological Engineering 36: 1365-1372.

Celentano D, Zahawi RA, Finegan B, Casanoves F, Ostertag R, Cole RJ, et al. (2011) Restauración ecológica de bosques tropicales en Costa Rica: efecto de varios modelos en producción, acumulación y descomposición de hojarasca. Revista de Biología Tropical 59: 1323-1336.

Chazdon RL (2008) Beyond deforestation: restoring forests and ecosystem services on degraded lands. Science 320: 1458-1460.

CNF (2013) Metodología para realizar y presentar los informes de sobrevivencia inicial de las plantaciones forestales comerciales. 20p. http://www.conafor.gob.mx/apoyos/index.php/inicio/download/1422. Date consulted: June 6, 2015.

Favela LS (2010) Population variation in the endemic Pinus culminicola detected by RAPD. Polibotánica 30 : 55-67.

Ferrer C, Broca A (1999) El binomio agricultura - ganadería en los ecosistemas mediterráneos: pastoreo frente a desierto verde. Pastos 39: 309-344.

García M, Treviño E, Cantú C, González F (1999) Zonificación ecológica del Cerro Potosí, Galeana, Nuevo León, México. Investigaciones Geográficas 38: 31-40.

Gil C (2001) La restauración ecológica como una herramienta de conservación para el sur de Chile. Gestión Ambiental 7: 3-13.

Guzmán ÁJR, Navarro CRM (2005) Restauración ecológica de olivares marginales: potencialidades y limitaciones. Ecosistemas 14: 116-131.

Holl KD, Loik ME, Lin EHV, Samuels IA (2000) Tropical mountain forest restoration in Costa Rica: Overcoming barriers to dispersal and establishment. Restoration Ecology 8: 339-349.

Jackson L, Lopoukhine N, Hillyard D (1995) Ecological Restoration: A definition and comments. Restoration Ecology 3: 71-75.

Jiménez J, Kramer H, Aguirre O (1996) Pinus culminicola. Zur Entdeckung und Erhaltung einer mexikanischer Zwergkiefer. Forst und Holz 51: 664-667.

Jiménez J, Aguirre O, Treviño E, Jurado E, González M (1999) Patrones de desarrollo en un ecosistema de Pinus culminicola y $P$. hartwegii. Ciencia UANL 2: 149-154.

Jiménez J, Jurado E, Aguirre O, Estrada E (2005) Effect of Grazing on Restoration of Endemic Dwarf Pine (Pinus culminicola Andresen et Beaman) Populations in Northeastern Mexico. Restoration Ecology 13: 103-107.

Lamb D, Gilmour D (2003) Issues in forest conservation. Rehabilitation and restoration of degraded forests. International Union for Conservation of Nature and Natural Resources and The World Wide Fund for Nature. Gland, Switzerland. 110p.

López-Barrera F, Manson RH, González-Espinosa M, Newton AC (2007) Effects of varying forest edge permeability on seed dispersal in a Neotropical montane forest. Landscape Ecology 22: 189-203. 
Meli P (2003) Restauración ecológica de bosques tropicales. Veinte años de investigación académica. Interciencia 28: 581-589.

Myronidis DI, Emmanouloudis DA, Mitsopoulos IA, Riggos EE (2010) Soil Erosion Potential after Fire and Rehabilitation Treatments in Greece. Environmental Modeling and Assessment 15: 239-250.

Ruiz M, Mitchell T (2005) Restoration Success: How is it being measured? Restoration Ecology 13: 569-577.

SERI (2004) The primer on ecological restoration. Science and Policy Working Group. Washington D.C., USA. http://www.ser.org/resources/resources-detail-view/ser-international-primer-on-ecologicalrestoration. Date consulted: January 20, 2015.

SEMARNAT (2010) Norma Oficial Mexicana NOM-059- SEMARNAT-2010, Protección ambiental - Especies nativas de México de flora y fauna silvestres - Categorias de riesgo y especificaciones para su inclusion, exclución o cambio - Lista de especies en riesgo. Diario Oficial de la Federación. http://dof.gob.mx/nota detalle_popup.php?codigo=5173091. Date consulted: January 15, 2015.

Zimmerman JK, Pascarella JB, Aide TM (2000) Barriers to forest regeneration in an abandoned pasture in Puerto Rico. Restoration Ecology 8: 350-360. 
